\title{
Scotland, Northern Ireland, and Devolution, 1945-1979
}

\author{
Grabam Walker
}

W

hen, in 1968, Harold Wilson's Labour government set up a Royal Commission on the Constitution to examine devolution for Scotland and, to a lesser extent, Wales, it rarely reflected on the experience of Northern Ireland. By then the Province had possessed legislative devolution for almost half a century, the product of the Government of Ireland Act of 1920. When it eventually reported in 1973, the Royal Commission did include some consideration of the Northern Ireland precedent, but, as this article will show, it was a close-run matter that a study of Ulster should feature in the findings. As Tom Wilson pointed out in 1989, the commission's example was rarely followed; as Northern Ireland's political turmoil dragged on, fewer scholars saw profit in viewing it as anything other than a peculiarly troubled place with little of relevance for other parts of the United Kingdom. ${ }^{1}$

There is much to be gained in studying the interactions between Scotland and Northern Ireland in relation to devolution and constitutional change, provided that care is always taken to allow for the crucial differences in the respective contexts. ${ }^{2}$ The claims that these places in particular made on the attention of governments in the 1970s ensured the intensity of the constitutional debate that developed in that decade. This study seeks to bring to light the extent and nature of the interactions between the Scottish and Northern Irish cases from the end of the Second World War until the fall of the Callaghan government in 1979. In so doing, it is hoped that a valuable historical perspective on territorial politics, as called for by scholars like Jonathan Bradbury, will be supplied. ${ }^{3}$

Graham Walker is professor of political history at Queen's University, Belfast. He wishes to acknowledge the assistance of the Leverhulme Trust.

${ }^{1}$ Tom Wilson, Ulster: Conflict and Consent (Oxford, 1989), 64. A recent example is Michael O'Neill, Devolution (London, 2004), 41.

${ }^{2}$ See Graham Walker, "Scotland and Northern Ireland: Constitutional Questions, Connections and Possibilities," Government and Opposition 33, no. 1 (Winter 1998): 21-37.

${ }^{3}$ See Jonathan Bradbury, "Territory and Power Revisited: Theorising Territorial Politics in the United Kingdom after Devolution," Political Studies 54, no. 3 (October 2006): 559-82.

Journal of British Studies 49 (January 2010): 117-142

(C) 2010 by The North American Conference on British Studies.

All rights reserved. 0021-9371/2010/4901-0001\$10.00 
It will be demonstrated that the Northern Ireland example of devolution influenced debate on Scotland in the period following the Second World War much more than has been appreciated previously; the Ulster example was important to those constitutional thinkers in Scotland such as John P. Mackintosh who found themselves battling against a "Unitary State" tide of assumptions in British politics generally and the Labour Party in particular until the late 1960s. For those who kept the devolution cause alive in relation to Scotland, issues of national identity and greater democratic accountability drove their case, yet they also shared the outlook of the ruling Ulster Unionists in Northern Ireland around the notion that devolved government should serve to strengthen the Union, not attenuate it. Prodevolutionists in Scotland and elsewhere were anxious to counter the argument of the constitutional conservatives that devolution would lead to the breakup of the United Kingdom; Northern Ireland, although an example to be used with caution, lent support to their case. Devolution was central to the "Union State" perspective on the United Kingdom, which stressed the need for the accommodation of national diversity and viewed too much centralization or projects aimed at creating uniformity across the polity as inimical to the health and development of the Union. ${ }^{4}$

Notwithstanding the Labour Party's orientation toward a centralized British State from 1945, a general restructuring of the United Kingdom was nonetheless envisaged when the party was in government in the late 1960s. This was precisely the juncture at which the troubles broke out in Northern Ireland; otherwise, as will be indicated, the Province would most likely have been involved in any shakeup on the same terms as other parts of the United Kingdom. The evidence shows that the terms of reference of the Royal Commission on the Constitution set up in 1968 were actually revised in accordance with the Ulster premier's cooperation and wishes. Moreover, although the political crisis in Northern Ireland encouraged the view that its situation was unique, both the Royal Commission and Whitehall officials paid careful attention to the Northern Ireland experience of devolution in areas such as finance in assessing the form devolution might take for Scotland and Wales. Indeed, the work of the Royal Commission came to be viewed as a difficulty by the Conservative government led by Edward Heath from 1970 in its quest to find a peaceful solution for Ulster.

When Labour returned to power in 1974, it decided to pursue devolution for Scotland and Wales as recommended by the majority report of the Royal Commission. A somewhat reluctant Scottish Labour Party had to be dragged along this reforming route as the government confronted the Scottish National Party's (SNP) substantial electoral impact. Some continued to see devolution as an inappropriately panic-stricken response to nationalism as late as 1979. In Ulster, Unionists were in political disarray and fragmented into different parties and groups after the Stormont Parliament was taken away from them in 1972. Yet in the main there was agreement on the desirability of retrieving devolved power

\footnotetext{
${ }^{4}$ The "Union" and "Unitary" State concepts derive from Stein Rokkan and Derek Urwin, "Introduction: Centre and Peripheries in Western Europe," in The Politics of Territorial Identity: Studies in European Regionalism, ed. Stein Rokkan and Derek Urwin (London, 1982), 1-18. See the discussion in relation to Scotland in James Mitchell, "Scotland in the Union, 1945-95: The Changing Nature of the Union State," in Scotland in the 20th Century, ed. T. M. Devine and R. J. Finlay (Edinburgh, 1996), 85-101.
} 
and, indeed, the majority-rule form of it they had previously enjoyed with their Parliament at Stormont. It will be contended that the prospect of devolution in an "old Stormont" form for Scotland and Wales at this juncture encouraged antipower-sharing Unionists (decidedly the majority) to use the issue as political leverage and to continue to press for majority-rule devolution for Northern Ireland. This had an important bearing on the failure of the Constitutional Convention of 1975. In addition, it will be suggested that the Northern Ireland Office, having pushed its way on to crucial working groups on devolution set up in late 1974, provided significant input of a conservative constitutional nature.

Overall, this article will attempt to show that there are great benefits for our understanding of the history and workings of the United Kingdom and of the national and ethnic tensions that have characterized it, in bringing Northern Ireland more emphatically into the fold of constitutional analysis and in investigating the interactions between the different devolutionary cases.

\section{SCOTTISH HOME RULE AND THE STORMONT MODEL}

The immediate postwar period witnessed a considerable rise of interest in the question of Scottish Home Rule, as the Westminster Labour government was forced to address grievances grounded in national identity. The government's centralizing dynamic, combined with its program of nationalization, appeared to many Scots to threaten the distinctiveness of the Scottish position within the United Kingdom. The growth of central economic planning seemed to lock Scotland into the British economy in a way that allowed little or no room for arrangements for special Scottish needs and Scottish control of its own industry. In a context in which unemployment was twice as high in Scotland as in England, such fears and doubts were easily exploited by those in favor of constitutional change. By 1947 this group had organized a "Scottish National Assembly" (SNA)—a crossparty and broadly representative body-that protested about the centralization practiced by the Labour government and called for a separate Scottish Parliament based on the example of Stormont in Northern Ireland. In 1949 the SNA organized the signing of a covenant, which eventually secured some 2 million names, in favor of a Scottish Parliament with tax-raising powers within the framework of the United Kingdom. ${ }^{5}$

The adoption of the Northern Ireland model by Scottish Home Rulers was not done in a precise manner, but it clearly was felt that the one existing example of legislative devolution in the United Kingdom was a useful reference point. This was also the view of those in Whitehall entrusted with the task of responding to the Scottish demands. Consequently, during the late 1940s, there was an unprecedented curiosity in quarters outside of Irish politics concerning the way that Stormont functioned and whether or not devolution had been a success in Northern Ireland from its inception in 1921 until that point.

The investigations conducted by civil servants focused on matters such as re-

\footnotetext{
${ }^{5}$ Of the literature on postwar Scottish politics and the Home Rule movement, see especially Ian Levitt, "Britain, the Scottish Covenant Movement and Devolution, 1946-50," Scottish Affairs, no. 22 (Winter 1998): 33-57.
} 
served and transferred powers, financial relations, and the position of MPs. ${ }^{6}$ The intention was to ascertain how closely the position in Scotland approximated to Northern Ireland in relation to the SNA's proposals on these matters. The approach of the inquiry clearly leaned toward a conservative constitutional position with stress being laid on those factors that could be said to undermine the case for the Stormont model being applied to Scotland. Much was therefore made of the fact that successive Northern Ireland governments, always of an Ulster Unionist Party (UUP) complexion, had opted to remain "step by step" with the rest of the United Kingdom in terms of social welfare benefits and services, even at the cost of effectively sacrificing the circumscribed financial powers they possessed under devolution. It was clear that Northern Ireland's history in relation to the "step by step" or "parity" principle, and the recasting of the financial basis to devolution that it had involved, was not something Whitehall wished to see repeated. ${ }^{7}$ This pointed to the ambiguous and arguably unsatisfactory nature of the financial relationship between London and Belfast that had developed since Northern Ireland's establishment as a devolved unit of the United Kingdom. ${ }^{8}$ The examination of the history of Northern Ireland's "Imperial Contribution," an obligation that had been reformulated in the Province's favor shortly after devolved government had begun, revealed that in a number of years during the 1930s it was at a very low level and more than offset by special payments from the UK Exchequer. Although this situation improved significantly during the war and in the immediate postwar years, it was concluded that even in 1949 it was doubtful if Northern Ireland in proportion to its population made "an adequate contribution to financial burdens falling on the whole UK."

What might be safely inferred is that Whitehall wished to avoid another situation like that of Northern Ireland in respect of the financial dimension to any devolution scheme that might be adopted for Scotland, especially in the new era of the welfare state and the extensive range of costly social services that had been applied across the United Kingdom. Moreover, it was likely that the political pressures that prevented Ulster Unionists making difficulties with London over finance would not apply in the case of Scotland, where there would be a stronger nationalist underpinning to the devolution objective. ${ }^{10}$ It was also felt to be anomalous that

\footnotetext{
${ }^{6}$ Position paper prepared for the Permanent Secretary of the Scottish Office, n.d., The National Archives (TNA): Public Record Office (PRO), CJ 1/89: Comparisons between powers of Northern Ireland Parliament and powers proposed to be conferred on a Scottish Parliament. The paper was accompanied by a note dated 2 December 1949 and signed "WSM" (William Murrie of the Home Office). See also memo by G. C. Cunningham dated 14 December 1949.

${ }^{7}$ In effect, Northern Ireland had moved by the Second World War from a "revenue-based" system of financing to an "expenditure-based" one which allowed Stormont to spend beyond its means to make up "leeway" in social services such as housing, education, and health. See the discussion in Vernon Bogdanor, Devolution in the United Kingdom, 2nd ed. (Oxford, 1999), chap. 3; and Arthur Green, Devolution and Public Finance: Stormont from 1921 to 1972 (Glasgow, 1979). For a contemporary appraisal of the finances of devolution in Northern Ireland, see Tom Wilson, "Devolution and Public Finance," in Ulster under Home Rule, ed. Tom Wilson (London, 1955), 115-36.

${ }^{8}$ See James Mitchell, "Undignified and Inefficient: Financial Relations between London and Stormont," Contemporary British History 20, no. 1 (March 2006): 57-73.

${ }^{9}$ Position paper to Permanent Secretary of Scottish Office, n.d., TNA: PRO, CJ 1/89.

${ }^{10}$ See John N. Wolfe, "Problems of Federal Financial Arrangements," in Government and Nationalism in Scotland, ed. John N. Wolfe (Edinburgh, 1969), 97; Gavin McCrone, Scotland's Future (Oxford, 1969), 93-99; and Reginald J. Lawrence, The Government of Northern Ireland (Oxford, 1965), 181.
} 
Northern Ireland should be in a position in which it could levy only a small fraction of its taxable income yet control so much of its expenditure.

The Northern Ireland example was regarded much more positively by that part of the Scottish press which took up the cause of the Scottish National Assembly and Covenant. Glowing reviews of Stormont's progress featured in popular papers such as the Scottish Daily Express and the Glasgow Bulletin. Articles in the Express highlighted the Province's impressive export figures and the advantages of the local devolved arrangements in terms of accessibility, and the responsiveness of local officials and politicians to inquiries and requests. ${ }^{11}$ The Bulletin's later campaign centered on the argument that "What Ulster can make work so can we in Scotland." 12 This paper's series of articles on the Northern Ireland example provided greater depth and at least some recognition of the problems caused by conflict between Unionists and Nationalists. However, the contention that Stormont could adapt Westminster legislation to suit local arrangements rather exaggerated the extent to which Northern Ireland chose to differ from the rest of the United Kingdom. The paper was on shaky ground in claiming that Northern Ireland enjoyed considerable freedom from "Whitehall interference." Agreements reached between Belfast and London over the extension of the welfare measures to the Province clearly produced a tightening of Treasury controls. ${ }^{13}$ The Scottish Home Rulers held such a rosy view of Stormont that a plebiscite organized in January 1949 in the Angus district of Kirriemuir asked voters to choose between three options: an independent Scottish Parliament, a Parliament like that of Northern Ireland, and no Scottish Parliament. Northern Ireland was explicitly referred to as the working example. Around 2,300 electors out of 2,600 voted, and the percentages broke down as 23.3 percent for the first option; 69 percent for the second; and 5.4 percent for the third, with 2.3 percent spoilt. ${ }^{14}$

The issue of Scottish devolution was viewed as a nuisance by the Attlee government. In 1947 the Lord President, Herbert Morrison, found his workload supplemented by the need for meetings with the Labour Party's Scottish Council, which was anxious to appear to respond in some way to the Home Rule agitation. Morrison resisted calls for inquiries and instructed the Scottish secretary, Josiah Westwood, to conduct a publicity campaign stressing the benefits to Scotland of the existing arrangements and the government's economic approach and social reforms. ${ }^{15}$ "The whole subject [devolution] is difficult," wrote Morrison to Westwood, "and arouses deep feelings and if we start up enquiries without a clear idea of our own policy we may be forced into courses of which we strongly disapprove. I should, for example, hope that you would resist any form of legislative devolution

\footnotetext{
${ }^{11}$ Ross Kennedy, “Ulster Has Made It Pay," Scottish Daily Express, 26 December 1947. See also 27 and 30 December 1947, respectively, in relation to the claim that Belfast-London relations were harmonious, and the Ulster government's efforts to attract new industries.

${ }^{12}$ Editorial, "Fifty Years of Scotland," Glasgow Bulletin, 31 December 1949.

13 "Free Ulster Is "Vetting' Bills from London," Glasgow Bulletin, 26 December 1949. For Treasury controls issue, see Francis N. Newark, "The Constitution of Northern Ireland," in Devolution of Government: The Experiment in Northern Ireland, ed. Francis N. Newark (London, 1953), 7-17.

${ }^{14}$ See Cunningham, memo, 14 December 1949, TNA: PRO, CJ 1/89; Arthur Turner, Scottish Home Rule (Oxford, 1952), 26; James Mitchell, Strategies for Self-Government (Edinburgh, 1996), 148-49.

${ }^{15}$ See documents in TNA: PRO, Prime Minister's Office (PREM) 8/658; also Richard Weight, Patriots (London, 2003), 127ff.
} 
which reproduced in Scotland the kind of arrangements in force in Northern Ireland." 16

Morrison knew Northern Ireland well and had in fact developed good working relationships with Ulster Unionist politicians, but the Province's political culture, grounded as it was in a dispute of an essentially nationalist kind, repelled him. ${ }^{17}$ He was decidedly typical of the prevailing outlook in the postwar British Labour movement that had come to regard nationalism as a reactionary force tainted with the fascism of the nationalist movements of interwar Europe. Moreover, it seemed to be a distraction from the politics of social progress and the improvement of the working class. Westwood's successor as Scottish secretary, Arthur Woodburn, represented the Scottish face of this antinationalist doctrine; he set about quelling the "excitable" elements in the Scottish press and elsewhere. ${ }^{18}$ In 1949, with the Covenant movement at its peak, Woodburn wrote to Hector McNeil, soon to be his successor as secretary of state, that the question "has, if anything, receded in relative importance to the political issues which are now dominating the scene." Woodburn reaffirmed the government's interest in improving the system of administrative devolution and pointed to his "modifications" of the Scottish Grand Committee at Westminster; but he was clearly more preoccupied with matters such as economic planning and the new Scottish Economic Conference he had introduced. ${ }^{19}$ When he took over from Woodburn, McNeil's main initiative concerned an inquiry into Scottish finances in their UK context. The report, when published in 1952, indicated the growing reliance of the Scottish economy on state subsidies. ${ }^{20}$ Clearly, Northern Ireland was not as exceptional as it was often painted.

Somewhat ironically, the admiring and envious looks from across the North Channel at Northern Ireland's constitutional position coincided with a significant degree of agitation for radical changes to these arrangements from within the Province itself. ${ }^{21}$ Indeed, this particular movement even embraced some leading members of the governing Ulster Unionists. A Unionist backbencher, W. F. McCoy, backed by certain members of the Stormont cabinet, began a campaign for greater autonomy and the conferral of dominion status and the placing of Northern Ireland on a par with Canada, Australia, New Zealand, and other mainstays of the Commonwealth. ${ }^{22}$ The "Dominion Status Lobby" was moved to embark on this venture-which McCoy in effect triggered with a key speech in August 1947on account of the Labour government's ascent to power in London. They feared that Labour, with its history of pro-Irish Nationalism, would be hostile to Ulster Unionist interests, and they were aghast at the prospect of socialist legislation being foisted upon Northern Ireland.

\footnotetext{
${ }^{16}$ Herbert Morrison to Josiah Westwood, 25 July 1947, TNA: PRO, PREM 8/658.

${ }^{17}$ See Brian Barton, "Relations between Westminster and Stormont during the Attlee Premiership," Irish Political Studies 7 (1992): 1-20.

${ }^{18}$ See David Torrance, The Scottish Secretaries (Edinburgh, 2006), 199.

${ }^{19}$ Arthur Woodburn to Hector McNeil, 14 November 1949, Acc. 7656 Box 1/1, National Library of Scotland (NLS).

${ }^{20}$ Torrance, Scottish Secretaries, 208.

${ }^{21}$ See comments in his diary by Ulster Premier Basil Brooke regarding the visit of Scottish Covenant representatives, 20 December 1949, Public Record Office of Northern Ireland (PRONI) D/3004/ $\mathrm{D} / 40$.

${ }^{22}$ See Graham Walker, A History of the Ulster Unionist Party (Manchester, 2004), 104-6.
} 
The advocates of dominion status certainly succeeded in generating a heated debate about the advantages and disadvantages of devolution that had more than passing relevance to the Scottish discussion of the time and later. McCoy contended that under the terms of the 1920 Act the Northern Ireland Parliament was "controlled and trammelled." He listed the restrictions on Stormont and pointed out that Westminster could intervene and override it as and when it wished; potentially, Westminster might even conclude an agreement with Dublin on Irish unity and impose it over the heads of Ulster. McCoy therefore ridiculed the notion of the 1920 Act as any kind of constitutional safeguard for Northern Ireland. The only way for the Province to secure its position in the empire, McCoy suggested, was a new constitution to enable it to legislate independently and remove it from the position of being "a shuttlecock in the game of party politics in England." McCoy also believed that Northern Ireland, subject since 1947 to even greater treasury control, had to break with the "step by step" policy on social welfare and make its own way on the basis of controlling its own level of taxation. As matters stood, Northern Ireland was only permitted to levy a small range of minor taxes. He was invincibly sanguine about the Province's ability to be economically self-sufficient due to the relatively strong health of its export trade. Freed from the burden of taxation imposed by Westminster and "the insupportable burden of expenditure" on the new socialist schemes, "capital and new industries would flood our country to enjoy the freedom of private enterprise."23

The Northern Ireland prime minister, Basil Brooke, and his predecessor and architect of the "step by step" policy, John M. Andrews, were forced to respond and to defend the existing position. Some of the arguments in this respect focused on claims of the greater security against the advances of Dublin still to be enjoyed as a full member of the United Kingdom, and there were serious doubts expressed as to the capacity of such a small unit as Northern Ireland to function as a dominion. ${ }^{24}$ Brooke also took pains to try to discredit the notion that Northern Ireland did not have meaningful scope to apply its own solutions to its own problems and played down the specter raised by McCoy about Westminster overriding Stormont: "Constitutional right was not constitutional usage." ${ }^{25}$ This was an interesting interpretation of the position that came to assume great significance within Ulster Unionism.

In the context of the postwar period and the Labour government's "New Jerusalem," Brooke and Andrews's counterthrust found its trump card in the crucial matter of maintaining the cross-class basis of support for the Union: "The Government is strongly supported by the votes of the working classes, who cherish their heritage in the Union, and to whom any tendency towards separation from Britain is anathema." ${ }^{26}$ Indeed, the need to ensure that the working class in Northern Ireland shared the benefits of postwar UK reconstruction bound the UUP to its "step by step" creed, notwithstanding the antisocialist sentiment to

\footnotetext{
${ }^{23}$ Cuttings 1947-53, W. F. McCoy Papers, PRONI D/3333/A/2. See especially article in the Unionist, January 1948, "Dominion Status for Northern Ireland."

${ }^{24}$ Basil Brooke, speech reported in the Derry Standard, 6 February 1948, PRONI D/3333/A/2.

${ }^{25}$ Cuttings 1947-53, W. F. McCoy Papers, PRONI D/3333/A/2. For report of "constitutional usage" claim, see Belfast Telegraph, 20 February 1948.

${ }^{26}$ Belfast News-Letter, 27 November 1947.
} 
be found in the Party. ${ }^{27}$ There could be no risks taken with the Protestant workingclass support for the Party, and it was precisely on this point about maintaining British standards of social welfare, by now far in advance of Southern Ireland, that McCoy and his colleagues were least convincing. It might be said that this was a debate that anticipated future Scottish deliberations over the purpose and potential of devolution, and the implications for British national identity and cohesiveness.

Fortunately for Brooke, he was able to reach such a satisfactory modus vivendi with the Labour government and to attain for Unionists what seemed to be a considerable symbolical strengthening of their position in the Ireland Act of 1949. This was the result of the British government having to redefine its position in response to Eire's decision the previous year to opt out of the Commonwealth and become a Republic. ${ }^{28}$ The act stipulated that Northern Ireland could only cease to be part of the United Kingdom with the consent of the Stormont parliament. This may not have theoretically cancelled out the ultimate right, enshrined in Section 75 of the 1920 Act, of London to trump Belfast in any constitutional dispute. Nevertheless, it understandably fed illusions of sovereignty on the part of Ulster Unionists and bolstered the claims of those who were inclined to regard Northern Ireland's relationship to the rest of the United Kingdom as a kind of "de facto federalism." 29 This was an issue that would be central to Unionist grievances when Stormont was prorogued in 1972. It was also the case that most observers and analysts of devolution at the time and since shared Brooke's belief in constitutional right not being translated into usage. Such an intervention, it was generally believed, would cause a constitutional crisis. However, what Brooke could not foresee were the circumstances in which "usage" was justified by a crisis in the Northern Ireland polity and civil disorder. Certainly, it can still be argued that the 1949 Act was an important landmark in the history of devolution not just for Northern Ireland, but for the United Kingdom as a whole and for the development of the debate about its constitutional character.

In addition, it might be observed that 1949 provided an opportunity for the Labour government to do some joined-up thinking about devolution and the constitution, especially in the light of the Scottish developments that have been noted. This was a juncture at which, for example, the Labour government might have placed the crucial business of intergovernmental relations with Belfast on to a more satisfactory basis and essayed a move away from the "ad hocery" and incoherence that had characterized such relations up to that point, particularly in relation to finance. ${ }^{30}$ The Labour government's actual conduct of these constitutional affairs in this period instead appears to supply empirical support to James Bulpitt's stress on the evolution of a center approach that placed emphasis on

\footnotetext{
${ }^{27}$ Walker, Ulster Unionist Party, 104-7; John E. Sayers, "The Political Parties and the Social Background," in Wilson, Ulster under Home Rule, 55-78.

${ }^{28}$ See Alvin Jackson, Home Rule: An Irish History (London, 2003), 254-55; Ian McCabe, A Diplomatic History of Ireland, 1948-49 (Dublin, 1991), chap. 9.

${ }^{29}$ See the discussion in Harry Calvert, Constitutional Law in Northern Ireland (London and Belfast, 1968), chap. 1; also Iain McLean and Alistair MacMillan, State of the Union (Oxford, 2005), 149-50, regarding the difficulties of interpreting the Act.

${ }^{30}$ See Mitchell, "Undignified and Inefficient."
} 
"centre autonomy."31 Such an approach involved a concentration on "high politics," and, notwithstanding the centralizing creed of the Attlee government on economic matters, a tendency to leave the periphery to its own political devices and a consciousness on the part of the political actors that it would not be proper to exceed limits at both center and periphery. ${ }^{32}$

The Ireland Act of 1949 took much of the steam out of the campaign for dominion status for Northern Ireland, but the issue was rejoined in the early 1950s in a toned-down manner. McCoy returned to the attack, although he was careful this time not to be explicit about the dominion status goal. Instead, he concentrated on pushing for radical changes to the financial relationship with Britain. "Treasury officials now take the place of the Northern Ireland Parliament and discharge the functions that once properly belonged to it," McCoy wrote in 1951..$^{33}$ These were eminently fair observations that had implications for those seeking a Northern Ireland style of devolution for Scotland. Nevertheless, Andrews was quick to denounce them as "separatist," a knee-jerk response that was also resorted to by critics of the Scottish proposals, Labour and otherwise. ${ }^{34}$

McCoy's critique of the operation of devolution in Northern Ireland indeed found some support from academics and commentators of the time. In 1952 Professor Charles Carter advocated more fiscal autonomy for Stormont, while back in 1950 a former comptroller and auditor-general for Northern Ireland, G. C. Duggan, claimed that Stormont's capacities had been "whittled down" by British government interventions over the years. ${ }^{35}$ Duggan, moreover, was highly critical of the Labour government's dealings with Scotland and what he believed were cosmetic gestures in the form of Woodburn's changes in Parliamentary procedures and a Scottish Economic Conference. Duggan argued that all devolution theorists, including those in the SNA, needed to face "the insoluble problem of relative tax capacities" and the many answers to the conundrum. To the Scots Duggan offered the following words of advice derived from the Northern Ireland experience: "A native institution cannot thrive on reach-me-down policies exported from Great Britain: they only clutter up the shelves of the local warehouse." ${ }^{36}$

In the same period, academics pondering the likelihood or advisability of devolution schemes for Scotland (and elsewhere) gave due consideration to the Northern Ireland example, and some concluded on it favorably. ${ }^{37}$ Arthur Turner, a Canadian political scientist, thought that the Province's significance as a test case was "encouraging," and he made similar points about the advantages of accessibility

\footnotetext{
${ }^{31}$ James Bulpitt, Territory and Power in the United Kingdom: An Interpretation (Manchester, 1983); see the discussion in Bradbury, "Territory and Power Revisited."

${ }^{32}$ See the discussion of Bulpitt's "Dual Politics" concept in Philip Norton, "Conservative Politics and the Abolition of Stormont," in The Northern Ireland Question in British Politics, ed. Peter Catterall and Sean McDougall (Basingstoke, 1996), 129-42; also see Mitchell, "Undignified and Inefficient," and his qualification of the Bulpitt argument regarding the substantial amount of civil service interaction between London and Belfast.

${ }^{33}$ Belfast News-Letter and Irish Times, 1 September 1951.

${ }^{34}$ Belfast News-Letter, 3 September 1951. For Scottish critics, see Levitt, "Britain."

${ }^{35}$ For Carter, see Northern Whig, 4 November 1952; for Duggan, "Northern Ireland-Success or Failure?" Irish Times, 19 April 1950.

36 "Northern Ireland-Success or Failure?" Irish Times, 3 May 1950.

${ }^{37}$ Apart from the examples discussed here, there was also the favorable verdict of Louis S. Amery, Thoughts on the Constitution, 2nd ed. (Oxford, 1953), 57-58.
} 
and the promotion of local democracy to those of the Scots admirers of Stormont. ${ }^{38}$ Reginald Coupland's more substantial study of Scottish and Welsh Nationalism noted that Northern Ireland's scheme had been operated so well that "Welsh and Scottish 'federalists' found themselves furnished with a new and powerful argument for the adoption of a similar system in Scotland and Wales." ${ }^{39}$ Another academic at the time, the constitutional legal expert F. H. Newark, also evaluated the Stormont experience with an eye on whether it might be copied in Scotland. However, he counseled caution, inclining to the conclusion that devolution in Northern Ireland had not made a significant enough difference. The reproduction of so much "parallel" legislation to that passed at Westminster, the tightening of the financial grip of the center on account of the application of the welfare measures to the Province, and the bar on Stormont discussing foreign affairs led Newark to suggest that the best option for Northern Ireland might be to reintegrate fully with the rest of the United Kingdom. ${ }^{40}$ In the first substantial academic study of the Northern Ireland case, Tom Wilson, a future adviser to the Stormont government, pointed out that devolution had not been sought in Northern Ireland by those motivated by Nationalist or separatist intent. "It is precisely when national sentiment demands Home Rule that Home Rule may do serious harm," he wrote, pithily summarizing what would later become a hardy annual of antidevolution argument in respect of Scotland. ${ }^{41}$

By the mid-1950s the campaign for a Scottish Parliament had come unstuck as the welfare state bedded down. ${ }^{42}$ The Conservatives, returned to power in 1951, made the concession of setting up a Royal Commission on Scottish Affairs, which finally reported in 1954. However, it was not designed to precipitate any fundamental changes to the administrative devolution arrangements. The commission did visit and study Northern Ireland before concluding that it would not "further the special needs and interests of Scotland" to adopt such a model. ${ }^{43}$ The report also indicated the extent to which expenditure on domestic services was relatively higher in Scotland than in England and Wales; arguably, if Scotland had taken the devolutionary route at this juncture a similar discussion about financial relations, "Imperial Contribution," parity ("step-by-step"), and subventions would have ensued.

In 1955 the Conservatives, or "Unionists" as they were commonly known, obtained over half the Scottish vote at the general election, a feat unique to this day. In 1958 the Scottish Council of the Labour Party felt able to drop its historic commitment to Scottish Home Rule. The "Woodburn" tendency was in the ascendant in the party, although it is notable that one of the few dissenters at the

\footnotetext{
${ }^{38}$ Turner, Scottish Home Rule, 55-56.

${ }^{39}$ Reginald Coupland, Welsh and Scottish Nationalism: A Study (London, 1954), 327-28.

${ }^{40}$ Newark, "The Constitution of Northern Ireland." See also Tom Teevan, "Devolution: Success or Failure?" Irish Times, 1 July 1952. Teevan was a prominent Ulster Unionist.

${ }^{41}$ Wilson, Ulster under Home Rule, 211.

${ }^{42}$ See Nicola McEwen, "State Welfare Nationalism: The Territorial Impact of Welfare State Development in Scotland," Regional and Federal Studies 12, no. I (Spring 2002): 66-90.

${ }^{43}$ Royal Commission on Scottish Affairs, 1952-1954, Cmnd. 9212 (London, 1954), 53 and 97.
} 
time was John P. Mackintosh, later to become one of the most cogent advocates of devolution and constitutional change when the debate was reignited. ${ }^{44}$

\section{DEVOLUTION ON THE AGENDA: THE WILSON AND HEATH GOVERNMENTS}

During the long period of Conservative government in the 1950s and early 1960s, the "dual politics" / "centre autonomy" approach became further entrenched with deleterious consequences for Northern Ireland, especially economically. Notwithstanding the integration of the Province's economy with that of the United Kingdom and the impact of central government policies on Northern Ireland's conspicuously higher unemployment rate in this period, there was no shifting the perspective of successive Tory governments that the responsibility to address the problem lay in Belfast. By the time Brooke (by now Lord Brookeborough) retired as Ulster prime minister in 1963 his Unionist government had been deeply discredited by its failure to wring concessions from London, and it had lost political ground to the Northern Ireland Labour Party (NILP). ${ }^{45}$ There was a widespread feeling, particularly among working-class voters, that Northern Ireland had been left out of the new wave of regional planning and development affecting the rest of the United Kingdom. Scotland's economic problems at this time bore many resemblances to those of Northern Ireland; nevertheless, Scotland's representation in the government through the secretary of state, the Scottish Office administrative arrangements, and the distinctive conduct of Scottish business at Westminster left it better placed than Northern Ireland to shape the policies that affected it. ${ }^{46}$

The new Northern Ireland premier, Terence O'Neill, immediately made a point of stressing economic modernization and the need to construct regional development plans for the Province. O'Neill could be said to have acted in a way designed to win back the favor of central government by switching the emphasis from "step by step" to "self help." ${ }^{\prime 7}$ However, he was also concerned to ensure that Northern Ireland would not become further marginalized in the context of the United Kingdom. Indeed, he was the first Northern Ireland premier to evangelize about the merits of devolution and to foresee and encourage its extension to other parts of the United Kingdom. ${ }^{48}$ O'Neill was keen to highlight examples of Northern Ireland using its powers to diverge from London, and such examples would become much more numerous during his years in office. O'Neill was inevitably sensitive about arguments concerning "subsidies" to Northern Ireland"one cannot assess the contribution which a region makes to the whole nation in purely budgetary terms"-although he talked openly of subsidies to his colleagues when under pressure from London to initiate reforms to address the grievances

\footnotetext{
${ }^{44}$ See Greg Rosen, “John P. Mackintosh: His Achievements and Legacy," Political Quarterly 70, no. 2 (April-June 1999): 210-18.

${ }^{45}$ See Walker, Ulster Unionist Party, 126-28, 139-47.

${ }^{46}$ See Lawrence, Government of Northern Ireland, 174.

${ }^{47}$ See Mark Mulholland, Northern Ireland at the Crossroads (London, 2000), 19.

${ }^{48}$ See Terence O'Neill, Ulster at the Crossroads (London, 1969), speeches in chap. 3 from earlier in his premiership.
} 
of the Catholic and Nationalist minority. ${ }^{49}$ O'Neill's goal was a "regional patriotism" that would transcend old sectarian divisions and also, crucially, steer clear of class politics. ${ }^{50}$ Indeed, O'Neill saw Ulster as possibly providing an example to the rest of the United Kingdom in this latter respect.

O'Neill's vision of communal harmony was mocked by the spiraling unrest in Northern Ireland from the mid-1960s, and he resigned the premiership in 1969 as the Province was on the brink of the troubles that were to scar it for a quarter of a century. By then he appeared prescient about the possible spread of devolution in the United Kingdom, for the rise of nationalism in Scotland and to some extent in Wales had piloted the issue on to the agenda of central government. ${ }^{51}$ Moreover, as Tanner has argued, the Wilson Labour government, elected first in 1964 and then again in 1966, had shown significant interest in the reform of local government and the possibilities of new regional tiers of government throughout Britain. The case for change was driven inside the cabinet by Richard Crossman, who received no encouragement from Scottish secretary Willie Ross. ${ }^{52}$

Ross was typical of the Scottish Labour Party's outlook during the 1960s. The party's point of reference was the British state and the assumption that social and economic progress was dependent on centralization. Labour was stunned by the backlash against the government's economic ills following their return to office in 1966, and especially the Nationalist form that this took in Scotland. In 1967 the SNP won a by-election in the Labour stronghold of Hamilton and a raft of seats in the local government elections of the following year. However, Ross and other Scottish Labour leadership figures essentially regarded the Nationalist threat as a protest vote and thus an ephemeral phenomenon; at all costs it was necessary not to pander to it. ${ }^{53}$ They viewed the government's decision to set up a Royal Commission on the Constitution late in 1968 as a device that would have the effect of burying devolution as an issue. ${ }^{54}$ Ross and the bulk of the Scottish Labour movement feared that devolution would reduce Scottish representation at Westminster and curtail Scottish influences on central government. ${ }^{55}$

A minority tendency within Scottish Labour, led by Mackintosh, instead pointed to the way that the administrative devolution possessed by Scotland had expanded to encompass new economic responsibilities and argued that there was a strong case for democratic control over, and scrutiny of, these administrative bodies and

${ }^{49}$ Ibid., speech to North Belfast Unionist Association. For the subsidies point, see Henry Patterson and Eric Kaufmann, Unionism and Orangeism in Northern Ireland since 1945 (Manchester, 2007), 80 .

${ }^{50}$ Mulholland, Northern Ireland, 26.

${ }^{51}$ See James Mitchell, "Scottish Nationalism and Demands for Devolution," in The Labour Governments, 1964-70, ed. Peter Dorey (Abingdon, 2006), 193-208.

${ }^{52}$ See Duncan Tanner, "Richard Crossman, Harold Wilson and Devolution, 1966-70," Twentieth Century British History 17, no. 4 (2006): 545-78.

${ }^{53}$ See Greg Rosen, Old Labour into New (London, 2005), 360-67; Torrance, Scottish Secretaries, 248-69.

${ }^{54}$ See Chris Harvie and Peter Jones, The Road to Home Rule (Edinburgh, 2000), 90; Tanner, "Richard Crossman."

${ }^{55}$ Bogdanor, Devolution, 168-70. In 1965 Harold Wilson had raised the issue of Ulster Unionist MPs at Westminster voting on matters that did not strictly relate to Northern Ireland; see note of meeting between Wilson and O’Neill, 19 May 1965, TNA: PRO, PREM 13/1663. 
processes. ${ }^{56}$ Mackintosh made such a case in a book published just as the SNP was on the rise. In it he referred to the Northern Ireland example to support his case, arguing that the Province's history of parity in social services within a devolutionary context was evidence that devolution would not lead to separation. ${ }^{57}$

Consideration of the terms of reference for the Royal Commission, chaired initially by Lord Crowther, led to discussion about Northern Ireland's involvement. ${ }^{58}$ The setting-up of the commission coincided with the first serious disturbances surrounding the civil rights movement in Northern Ireland, and there was concern that including the Province in the commission's deliberations should not deflect attention from the reforms then being urged on O'Neill by the Wilson government. ${ }^{59}$ However, in a letter to O'Neill, Home Office official Brian Cubbon assured him that there would be "no derogation" from the provision in the 1949 Act under which Northern Ireland would not cease to be part of the United Kingdom without the consent of the Stormont Parliament. Moreover, he also stated what he believed to be the broader reasons for Northern Ireland's inclusion: "It is not simply that the divisions of responsibility between our Parliaments and governments [have] been the subject of a good deal of questioning here and that the unique constitutional pattern set up by the 1920 Act must clearly be in the greatest interest in such an inquiry; more important is the consideration that we can no longer profitably deal with questions of government within the United Kingdom piecemeal, country by country. We need to look at the whole." ${ }^{60}$

This was an interesting statement in its all-embracing conceptualization of constitutional reform. Yet it was an approach that was not carried forward by future governments whether in the 1970s or the 1990s, when largely piecemeal proposals and solutions were in fact adopted. Besides that, however, Cubbon's perspective gives rise to an intriguing counterfactual question: if the troubles in Northern Ireland had not broken out at precisely this juncture, was there a likelihood of a restructuring of the United Kingdom along the time-honored lines of "Home Rule All Round" that would have dispelled the notion of Northern Ireland as a place apart? ${ }^{61}$ Such a restructuring would also have made obligatory the requisite democratic reforms in Northern Ireland to rectify past ill-treatment of the minority.

The first stirrings of trouble in Northern Ireland nonetheless made the political actors cautious. Jeremy Thorpe, the Liberal leader, and Edward Heath, the leader of the Conservative opposition, both raised the issue of separate treatment for the Province, and Crowther himself seemed nervous about the wide scope of the inquiry as it appeared to be envisaged..$^{62}$ O'Neill replied to Wilson confirming his and his colleagues' support for Northern Ireland's involvement but was worried about the use of the word "constitutional" and wanted it made clear that "the 39.

${ }^{56}$ Henry Drucker and Gordon Brown, The Politics of Nationalism and Devolution (London, 1980),

${ }^{57}$ John P. Mackintosh, The Devolution of Power (Harmondsworth, 1968), 181-82.

${ }^{58}$ Memo to the Prime Minister, 23 October 1968, TNA: PRO PREM 13/3259.

${ }^{59}$ Memo to the Prime Minister, 28 October 1968, TNA: PRO, PREM 13/3259.

${ }^{60}$ Brian Cubbon to Terence O'Neill, 11 November 1968, TNA: PRO, PREM 13/3259.

${ }^{61}$ For which, see John Kendle, Federal Britain (London, 1997).

${ }^{62}$ Memo re meeting between Jeremy Thorpe and James Callaghan, 4 December 1968; Heath and Callaghan, 4 December 1968; and note of meeting re Crowther, 22 November 1968, TNA: PRO, PREM 13/3259. 
essential unity and territorial integrity" of the United Kingdom was not in question. O'Neill believed that no time should be wasted on "the unrealistic theories of extreme nationalism." "63 To appease O'Neill the terms of reference were revised to include the term "our people under the Crown," a change that made Northern Ireland feel that it belonged. However, it was also made clear that the "separatist" arguments would have to be heard, notwithstanding the unlikelihood of any recommendations being made in this direction. ${ }^{64}$ Representatives from Northern Ireland were included on the commission, including Professor Newark, whose earlier skeptical views on the benefits of devolution have already been noted.

Meanwhile, at the start of 1970 an antidevolutionary report submitted to the Royal Commission by the Scottish Council of the Labour Party revealed the gulf that had opened up between it and the Labour leadership in London. ${ }^{65}$ This resulted in Premier Wilson leaning on Ross to bring Scotland to heel, although it is doubtful that Ross would have favored even the modest proposal of the Conservatives at this juncture of a "Scottish Convention" to debate the Second Reading, Committee, and Report stages of bills applying to Scotland. ${ }^{66}$

After coming to power in June 1970, the Conservatives in effect pushed the issue of devolution for Scotland to the margins, notwithstanding their manifesto commitment to the Scottish Convention. In Northern Ireland escalating political turmoil and violence saw the Heath government flounder in response. Confidence in the creaking Ulster Unionist administration of James Chichester-Clark was clearly low in London, yet the alternative of direct rule from Westminster was regarded with dread. In March 1971, when Chichester-Clark resigned over the security situation, he was replaced by Brian Faulkner, who was evidently viewed as London's last hope regarding the reestablishment of political stability in the Province. London reluctantly backed Faulkner's decision to bring in internment without trial in August 1971 but warned him that in the event of its failure the next step was direct rule. ${ }^{67}$ Heath clearly had grave doubts that internment would prove successful and was forced to ponder the implications of London assuming control. In desperation, he turned to the Commission on the Constitution, asking for "any useful proposal for reform" in the Northern Ireland evidence it had thus far accumulated. ${ }^{68}$ The commission had taken such evidence from the previous year. Heath was told that the interim conclusions were that Stormont had "operated as well as could be imagined; that most of the real difficulties and legitimate criticisms about gerrymandering and so forth related to local government, which was in course of being dealt with, and that they had no changes to suggest." A deflated Heath suggested that it would be better that the commission did not put out an interim report. ${ }^{69}$

In February 1972, on the death of Lord Crowther, the chairmanship of the commission was taken up by Lord Kilbrandon, who considered dropping Northern

${ }^{63}$ O'Neill to Wilson, 6 December 1968, TNA: PRO, PREM 13/3259.

${ }^{64}$ Cubbon to Peter Gregson, 20 December 1968, TNA: PRO, PREM 13/3259.

${ }^{65}$ Peter Shore to Gerald Kaufman, 6 January 1970, TNA: PRO, PREM 13/3259.

${ }^{66}$ Willie Ross to Wilson, 15 April 1970, TNA: PRO, PREM 13/3259; Scottish Office memo and Douglas-Home Committee Report, 18 March 1970, TNA: PRO, PREM 13/3259.

${ }^{67}$ Walker, Ulster Unionist Party, 192.

${ }^{68}$ Gregson to Joseph Pilling (Home Office), 13 August 1971, TNA: PRO, CJ 4/338.

${ }^{69}$ Gregson memo, 19 August 1971, TNA: PRO, CJ 4/338. 
Ireland from its remit. ${ }^{70}$ The question became more pressing in view of the suspension of Stormont in March, and evidence taken in 1970 and 1971 was regarded as having dubious value in the circumstances of the imposition of direct rule. In September, Heath stated that he did not think that William Whitelaw, the new secretary of state for Northern Ireland, could relieve the commission of the task of reporting on Northern Ireland. ${ }^{71}$ Whitelaw in fact met with Kilbrandon in November, the object, according to a briefing paper prepared for him, being to allow him to draw informally on the commission's knowledge and to obviate any later accusation that the commission had been ignored in relation to Northern Ireland. Whitelaw was to say that the study made of the Province should be published, but that no recommendations concerning Northern Ireland ought to be made. The commission's findings would have "historical value" but were not to be the basis for the government's thinking or future planning. ${ }^{72}$

As other memoranda and communications made clear, the government feared that those Ulster Unionists opposed to Heath and Whitelaw's wish to pursue the solution of a power-sharing Executive for Northern Ireland would seize upon the Kilbrandon Report's "clean bill of health" for the old Stormont. ${ }^{73}$ Heath and Whitelaw did not want Kilbrandon to impede the major policy initiative of a cross-community government that they were planning for Northern Ireland. This now eclipsed all consideration of devolution for other parts of the United Kingdom. They wanted Northern Ireland to be treated entirely separately as an example of a historic advance being made out of a unique crisis. The government, despite having tried to pillage the commission's findings early in its term of office, did not now wish to encourage cross-fertilization between the Northern Ireland case and the devolution issue more widely, which meant, in particular, devolution for Scotland. In March 1973, Lord Kilbrandon tried to reassure the government by saying that its White Paper proposals for Northern Ireland were in line with his report. ${ }^{74}$ The Scottish secretary of state, Gordon Campbell, stated that he would wait on Kilbrandon before drawing conclusions about a possible Scottish Assembly. ${ }^{75}$

It was difficult to prevent the Northern Irish and the Scottish issues from intersecting. In March 1973, the Scottish Liberal MPs Jo Grimond and David Steel, a past and a future party leader, respectively, intervened to link the initiative for Northern Ireland to calls for progress on Scotland. Steel, in line with Liberal policy, viewed the White Paper as a blueprint for more democratic government in Scotland with its proposals for a proportional representation electoral system and some in-built power sharing on committees. "If these plans can be applied to the unnatural unit of Ulster," he said in a widely reported speech, "they can

\footnotetext{
${ }^{70}$ Memo dated 7 February 1972, TNA: PRO, CJ 4/338.

${ }^{71}$ Robert Armstrong to Robert Stevens, 27 September 1972, TNA: PRO, CJ 4/338.

${ }^{72}$ Paper dated 22 November 1972, TNA: PRO, CJ 4/338.

${ }^{73}$ Dennis Trevelyan to Philip Woodfield, 21 November 1972, TNA: PRO, CJ 4/338. For the "clean bill of health" point, see comment by John Oliver in his "The Stormont Administration, 1921-72," contained in his book Aspects of Ulster (Antrim, 1994), 105-32. Oliver was a senior civil servant at Stormont during the 1960s and 1970s.

${ }^{74}$ Note of meeting, 16 March 1973, TNA: PRO, CJ 4/338.

${ }^{75}$ Gordon Campbell to Neave, 26 March 1973, TNA: PRO, CJ 4/338.
} 
surely apply to the natural entity of Scotland." ${ }^{76}$ For his part, Grimond pressured the government in a similar fashion with a parliamentary question for Gordon Campbell. ${ }^{77}$ The carefully prepared reply for Campbell was that there were many "fundamental differences" between Northern Ireland and Scotland and that there was no reason why a common form of devolution should be adopted. ${ }^{78}$

Notwithstanding Lord Kilbrandon's assurances back in March, Heath remained anxious about possible recommendations for "Stormont-style" devolution for Scotland and Wales, building on the evidence that such a system had worked well in Northern Ireland on its own merits and could not be viewed as the source of the troubles. ${ }^{79}$ The idea of delay in publication of the Kilbrandon Report was floated as a way out of the (immediate) difficulties. ${ }^{80}$

In the event, the government allowed publication to go ahead in late October, although even in the early days of that month there were worries expressed that recommendations in the report in respect of England, Scotland, and Wales could be "picked on in Northern Ireland to make trouble." ${ }^{81}$ The report in fact contained a substantial amount of material on the Northern Ireland experience of devolution, and it seems clear that this helped to shape some of the commission's conclusions about the financial aspects of devolution for Scotland and Wales. For example, it was concluded that applying the parity principle service by service, as it came to operate in Northern Ireland, would not be advisable for Scotland or Wales. ${ }^{82}$ The commission, however, noted that the evidence taken in 1970-71 had been overtaken by subsequent events and that it became necessary to "reconsider our role in relation to the province." ${ }^{83}$ It would be fair to add that the commission had been given a firm nudge in this direction by the Heath government, and that this resulted in the commission declining to offer any recommendations pertaining to Northern Ireland, with the exception of the issue of parliamentary representationwhich it proposed should be increased. It may have been the case that Kilbrandon, on taking over the chairmanship, was not inclined to venture far into the treacherous waters of Ulster, but it can be suggested that the factor of government pressure, as detailed above, was decisively brought to bear. It can also be hazarded that the report's mention in the conclusions of Stormont's past failure to make adequate provision for "the protection of the interests of the minority and for participation by the minority in government," was somewhat contrived to complement the proposal at the center of the government's Northern Ireland initiative. ${ }^{84}$ It would also have been gratifying to the government that the report stressed the differences between what might be appropriate for Northern Ireland and not

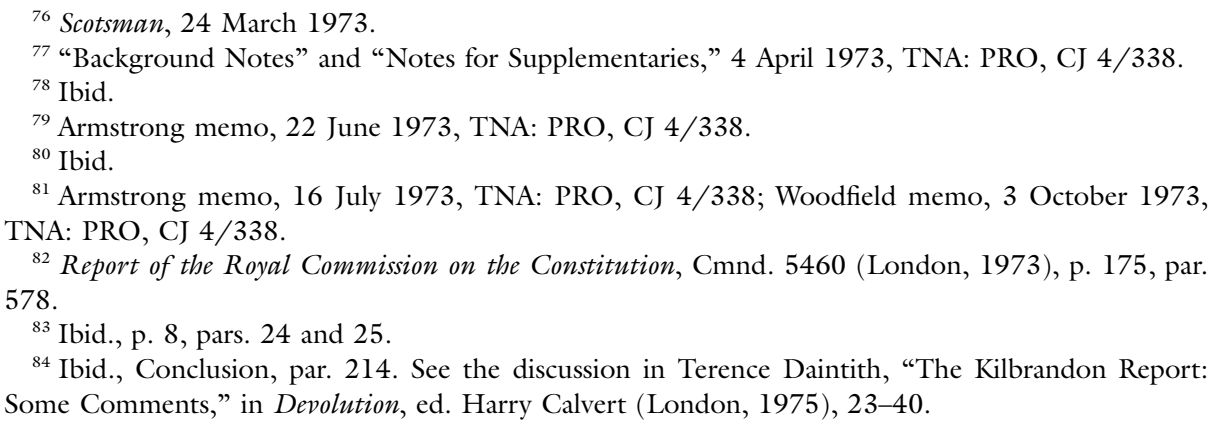


for Scotland and Wales, and vice versa. ${ }^{85}$ However, as was pointed out by a Northern Ireland Office official, the financial arrangements that the commission was proposing for Scotland and Wales were unlikely to provide the degree of independence that the commission was at pains to suggest would be a contrast with the Stormont experience. ${ }^{86}$ Moreover, on the matter of Northern Ireland's parliamentary representation, fears of the issue causing difficulties intensified almost immediately as the Ulster Unionists and their sympathizers in the House of Commons pressed for change. ${ }^{87}$ In the event, they had to wait for a change of government.

The suspension of the Stormont Parliament back in March 1972 had obviously transformed the relationship of Northern Ireland to the rest of the United Kingdom, and the mounting violence only underscored the need to treat the problem as a priority. Nevertheless, the wranglings over the Kilbrandon Report indicate that the problem of Northern Ireland's status and its future development could not be hived off easily from other constitutional matters. Indeed, the very act of proroguing Stormont raised searching questions about the nature of British constitutional thought and practice and the exercise of sovereignty by Westminster, and set a precedent with obvious relevance to future possibilities around devolution in the rest of the United Kingdom. ${ }^{88}$

While the suspension aroused no significant dissent at Westminster, such being the cross-party consensus over the failure of Brian Faulkner's government to restore law and order, Ulster Unionist reaction was generally indignant and bitter. ${ }^{89}$ There were some Unionists who took the view that the loss of Stormont could be tolerated, among them at the time Ian Paisley, who argued for the complete integration of the Province into the British state. However, others, like William Craig, leader of the Unionist Party pressure group Vanguard, argued stridently that the suspension amounted to an improper and unconstitutional interference with Northern Ireland's rights. He pointed to the provisions of the 1949 Act and seemed to claim that Northern Ireland in effect possessed the same status and rights as dominions such as Canada and New Zealand. Indeed, Vanguard soon adopted a pro-independence line and began agitating for a "Dominion Status" solution to the Northern Ireland problem, reviving the case argued back in the 1940s and 1950s by McCoy. ${ }^{90}$ Unionist perceptions of Westminster's "disregard for legality" over the prorogation of Stormont lingered on well into the decade and contributed to the difficulties of finding a solution in Northern Ireland to encompass both communities and the different identities and allegiances. ${ }^{91}$

The Heath government fell after the inconclusive general election of February

${ }^{85}$ Ian Burns (NIO) memo on Kilbrandon, n.d., TNA: PRO, CJ 4/338.

${ }^{86} \mathrm{Ibid}$.

87 "Ulster Should Have Still More MPs," Daily Telegraph, 16 November 1973.

${ }^{88}$ Such questions were to feature in the deliberations of the Scottish Constitutional Convention in the 1980s and 1990s.

${ }^{89}$ Heath had actually proposed that Westminster take over security powers and leave Faulkner to carry on governing in other areas; however, Faulkner and his cabinet would not entertain this. See discussion in Jackson, Home Rule, chap. 10.

${ }^{90}$ See Ulster Times, April, May, and June 1972; also the discussion in Patterson and Kaufman, Unionism and Orangeism, 147-61; and in David W. Miller, Queen's Rebels(Dublin, 1978), introduction and epilogue.

${ }^{91}$ Walker, Ulster Unionist Party, 223. 
1974. Wilson and Labour returned to office, albeit as a minority government. Furthermore, Labour now had to face seven SNP MPs at Westminster, the party having taken 22 percent of the Scottish vote. In the October 1974 election, which strengthened Labour's parliamentary position slightly, the SNP won eleven seats and actually polled 30 percent of the Scottish vote. It has been observed that the SNP was close to the point at which the ratio of votes to seats would swing "viciously" in its favor. ${ }^{92}$ Scottish devolution was firmly back on the horizon; indeed, it had been so since the coincidence of the Kilbrandon Report's appearance and a spectacular SNP by-election victory in Glasgow Govan in November 1973. The February 1974 election also proved the death knell for the Northern Ireland power-sharing Executive that was the result of Heath and Whitelaw's efforts during 1972-73. The outcome of the vote put the anti-Executive Ulster Unionists in the driving seat, and the Ulster Workers Council Strike of May 1974 merely brought the experiment down sooner rather than later. The Wilson government was now faced, like its predecessor in 1972, with the task of bringing peace to Northern Ireland while juggling other constitutional challenges.

\section{WILSON'S LAST YEARS: THE ULSTER CONVENTION AND THE WHITE PAPER ON DEVOLUTION}

In opposing the formation of the Northern Ireland power-sharing Executive and the provision for an all-Ireland Council, the various Unionist political groups concerned gathered under the umbrella of the United Ulster Unionist Council (UUUC). The UUUC issued a policy document at the beginning of 1974 that envisioned Northern Ireland becoming an integral part of a devolving United Kingdom along the lines suggested by the (majority) Kilbrandon Report. ${ }^{93}$ The UUUC was to hold together until 1977, and its demand to be included in any devolutionary restructuring of the United Kingdom exacerbated the problems faced by the British government and Whitehall in relation both to devolution and the conflict in Northern Ireland.

While Wilson's minority government attempted to progress devolution for Scotland and Wales, the new Northern Ireland secretary, Merlyn Rees, opted for a locally elected constitutional convention to consider what form of government might have the most support throughout the community. ${ }^{94}$ Rees was influenced by what he regarded as a growing "Ulster nationalism." ${ }^{95}$ Furthermore, Donoughue has attested to Rees's conviction by May 1975 that Ulster had to be progressively distanced from the rest of the United Kingdom. ${ }^{96}$ However, the last years of a Wilson-led Labour government were to illustrate the difficulties of disentangling the claims, demands, and needs of the different parts of the United Kingdom in accordance with the government's wishes.

Officials in the Northern Ireland Office (NIO), however, were concerned that

\footnotetext{
${ }^{92}$ McLean and MacMillan, State of the Union, 161-62. 94.

${ }^{93}$ See Eric Kaufmann, The Orange Order: A Contemporary Northern Irish History (Oxford, 2007),

${ }^{94}$ Merlyn Rees, Northern Ireland: A Personal History (London, 1985), chaps. 8 and 10.

${ }^{95}$ Kenneth Bloomfield, A Tragedy of Errors (Liverpool, 2007), 51.

${ }^{96}$ See Bernard Donoughue, Downing Street Diary (London, 2006), 387.
} 
the White Paper on devolution for Scotland and Wales could give rise to the demand for devolution for Northern Ireland on similar terms and that it might no longer be a feasible policy to justify measures for Northern Ireland merely on the grounds that it was different from any other part of the United Kingdom. ${ }^{97}$ They also pointed out that Northern Ireland's links with Scotland were much closer than with any other part of the United Kingdom and that there would thus be "a very heavy demand" from the Ulster community for parity of treatment with Scotland..$^{98}$

Rees himself was forced to acknowledge in September 1974 that there was "a strong inter-connection" between the problem of the constitutional future of Northern Ireland and the problems of devolution to Scotland and Wales, and was more than aware of the pressure the government would come under to apply to Northern Ireland features of the government's proposals for Scotland and Wales. ${ }^{99}$ Indeed, in January 1975 in Cabinet he pronounced himself opposed to speedy action on devolution for Scotland and Wales since it would disturb his work on Northern Ireland. ${ }^{100}$ Ken Bloomfield, the veteran civil servant who had been a close adviser of Terence O'Neill in the old days of Stormont, also urged those guiding matters for Scotland and Wales to be aware of the "Northern Ireland significance" of any scheme proposed. "In general terms," Bloomfield argued, "the further the final Scottish arrangements are from a 'winner takes all' majority party 'Cabinet' system, the better from our point of view. Some form of Scottish Committee system which involved a wider sharing of responsibility between parties would obviously make 'partnership' a more saleable commodity here."101

From the reelection of the Labour government in October 1974, this time with a majority of three seats, it is clear that the NIO was alive to the interrelatedness of the government's by now clearly mapped plans for Scotland and Wales, and its handling of the Northern Ireland problem. The NIO did not want to be sidelined and wished to preempt possible problems arising out of insufficient coordination of the two strands of government policy. It was felt that the Northern Ireland experience might be relevant on questions of intergovernmental relations, on finance, on the role of the secretary of state, and on the question of the dominance of one political party. ${ }^{102}$

The NIO's assertiveness successfully acquired representation on the devolution working groups set up at the end of 1974 by the Constitution Unit. The unit, part of the Cabinet Office, was formed to coordinate the government's devolution policy and to look into the details of how it would work in practice. The Northern Ireland input was to be particularly felt in relation to the Constitutional Arrangements Group and the Functions Group, and on matters such as override powers,

\footnotetext{
${ }^{97}$ Burns memo, 5 August 1974, TNA: PRO, CJ 4/536.

${ }^{98}$ Frank Cooper to John Hunt, 12 August 1974, TNA: PRO, CJ 4/536.

${ }^{99}$ Merlyn Rees to Lord Crowther-Hunt, 16 September 1974, TNA: PRO, CJ 4/536.

${ }^{100}$ See Donoughue, Diary (17 January 1975), 285.

${ }^{101}$ Kenneth Bloomfield to Cooper, 14 October 1974, TNA: PRO, CJ 4/536. Bloomfield was not to get his wish in relation to proposals for Scotland, although it might be said that there was more of a spirit of sharing between parties in the Welsh proposals. See Our Changing Democracy: Devolution to Scotland and Wales, Cmnd. 6348 (London, 1975), 38-39.

${ }^{102}$ Bloomfield to Cooper, 14 October 1974, TNA: PRO, CJ 4/536.
} 
"ultra vires" legislation, privileges, and the question of membership of different parliaments. ${ }^{103}$

By mid-1975, as the government's proposals for Scotland and Wales were firming up, the question of the repercussions for Northern Ireland emerged. It was observed in a Cabinet Committee on devolution that the government seemed to be creating for Scotland the kind of system that had existed in Northern Ireland before direct rule and that the Ulster Loyalists would demand the same kind of wide constitutional and executive freedom, based on majority rule rather than power sharing, that was being proposed for Scotland. It was pointed out that the timing of devolution thus had Northern Irish implications, and there is a clear sense of this factor being used in the committee to strengthen the case for caution and less speed regarding the Scottish question. ${ }^{104}$ This was a concern similar to that of the Heath government at the time of Kilbrandon, as documented above. By this time elections to the Northern Ireland convention had been held and the "Loyalists" referred to, meaning the UUUC, had polled nearly 55 percent of the vote and had secured forty-seven out of the seventy-five seats. Their manifesto had included the demand for "a democratically elected Parliament with a system of government broadly in line with the provisions to be made for constitutional devolution in the United Kingdom as a whole" and for full representation at Westminster, "the same in proportion to population as Scotland." 105 The UUUC opposed compulsory power sharing and was in fact to expel in October the Vanguard Loyalist leader William Craig for suggesting a voluntary coalition deal with the Nationalist Social Democratic and Labour Party (SDLP). ${ }^{106}$ The convention yielded nothing for the increasingly dismayed Rees to work with and was formally dissolved in March 1976. ${ }^{107}$ In his letter to the chairman of the convention Rees tortuously attempted to distinguish the Northern Irish case from the question of devolution in the rest of the United Kingdom and tendentiously referred to it being "outside the mainstream of discussion on devolution." 108 He also sent a memo to the prime minister warning that the option of holding a referendum on a power-sharing settlement for Northern Ireland would be likely to have unwelcome implications for the Scottish and Welsh cases. ${ }^{109}$

The two issues-achieving peace and stability in Northern Ireland and granting a measure of devolution to Scotland and a lesser one to Wales-clearly interacted significantly at this juncture. Conscious of the delicacy of the political situation in the Province, where violence continued even in the context of an Irish Republican Army (IRA) truce for some months, some officials, particularly in the NIO, sought

\footnotetext{
${ }^{103}$ Burns memo, 28 February 1975, TNA: PRO, CJ 4/747, and James (NIO) to John Garlick (Cabinet Office), 24 November 1974, TNA: PRO, CJ 4/744; Papers on "UK Powers to Override the Action of Scottish and Welsh Assemblies" (24 January 1975), and Ian Burns memo (n.d.), TNA: PRO, CJ 4/747; "Devolution: UltraVires" memo (n.d.), TNA: PRO, CJ 4/747; Burns memo, 7 April 1975, TNA: PRO, CJ 4/747; Burns memo, 7 April 1975, and Cook's reply, 11 April 1975, TNA: PRO, CJ $4 / 747$.

${ }^{104}$ See Minutes of Cabinet Committee on Devolution, 11 June 1975, TNA: PRO, CJ4/981.

${ }^{105}$ Richard Rose, Northern Ireland: A Time of Choice (Washington, DC, 1976), 81.

${ }^{106}$ Ibid., 129-32; see also the discussion in Jackson, Home Rule, 329-30, particularly in relation to the role of the future Ulster Unionist Party leader David Trimble.

${ }^{107}$ See Rees's Report on Northern Ireland, 4 March 1976, TNA: PRO, CAB (Cabinet) 128/58.

${ }^{108}$ Letter dated 12 January 1976, TNA: PRO, FC $87 / 554$.

${ }^{109}$ Memo dated 25 February 1976, TNA: PRO, FC 87/554.
} 
to prevent the broader devolution debate from unbalancing the government's calculations or, at least, from adding to the problems of creating a cross-community form of administration. Their influence may also be said to have contributed to the heavily circumscribed and limited forms of devolution for Scotland and Wales finally proposed in the White Paper of November 1975, which resulted in the departure from the Labour Party of two Scottish MPs and the transformation of the government into a minority one. ${ }^{110}$ Moreover, there has been insufficient appreciation of how much the UUUC's resistance to going down the road of power sharing and its tendency to cling to hopes of maximizing Ulster Unionist political objectives was shaped by developments around a devolution scheme for Scotland in particular which was so familiar to Unionists in Northern Ireland. Having so recently had such a system taken from them, it is perhaps unsurprising that the Unionists saw in the events relating to Scotland and Wales the hope of regaining it in a new context of greater constitutional security. In such a context Northern Ireland would not be an exception, but part of a broader UK process and framework.

This is not to suggest that Unionists were of one mind on devolution, simply to contend that their behavior and their strategy were clearly influenced by the broader UK devolution debate. The UUP leader, Harry West, had insisted to Rees back in 1974 that Unionists wanted "the same treatment as people in the rest of the United Kingdom plus the Kilbrandon proposals." prodevolution, seeing the United Kingdom as a set of partnerships and opposing only the imposition of compulsory power sharing. ${ }^{112}$ His allies in the party like David McNarry pointed out that what was being proposed for Scotland and Wales did not involve power sharing and that Northern Ireland should not accept anything less than "British standards of Regional Government." 113 West, McNarry, and others saw in the UK devolution issue the chance to get devolved government back quickly on their own terms.

However, others within Ulster Unionism seemed to be using the UK devolution issue for a different tactical purpose. In November 1975 Craig claimed that the Unionist Party leadership at Westminster, in effect James Molyneaux and Enoch Powell, were "anxious to put devolution on the long finger." 114 Molyneaux and Powell's "integrationist" Unionism has indeed been well acknowledged. ${ }^{115}$ It is arguable that they believed their objectives in this regard would be well served by bracketing Northern Ireland as much as possible with Scotland and Wales: "The devolution argument provided a fortuitous opportunity of playing the Northern Ireland question long," Powell is reported to have frankly admitted to the prime minister in October 1975. At this meeting he also referred to "the leverage of devolution" and his anxiety that Northern Ireland should not "move ahead of

\footnotetext{
${ }^{110}$ Our Changing Democracy. 784.

${ }^{111}$ Note of meeting between the Secretary of State and West, 30 May 1974, TNA: PRO, CJ 4/

112 "Why Unionists Seek Renewal of Partnership in the UK," The Times, 4 April 1974.

${ }^{113}$ David McNarry, speech, 18 February 1975, TNA: PRO, CJ 4/784.

${ }^{114}$ Note on meeting between Secretary of State and Vanguard Unionist Party members, 25 November 1975, TNA: PRO, CJ 4/1436.

${ }^{115}$ Walker, Ulster Unionist Party, 222-23; Simon Heffer, Like the Roman: The Life of Enoch Powell (London, 1999), 764-65.
} 
devolution in Scotland." ${ }^{116}$ While Powell felt able to make speeches to Ulster Unionist supporters pledging commitment to "the principle of devolved government for Ulster within the framework of the United Kingdom," he also clearly saw tactical advantage in insisting that it be on the same terms as Scotland and Wales and not on a "separate case" basis. ${ }^{117}$ However, unlike Craig, and in some contrast to the devolutionary enthusiasm of West, Powell and Molyneaux were content to wait, and the longer the wait the better. As Powell, scornful of Rees's convention and skeptical of the value of constitutional experiments in general, told Prime Minister Wilson, inertia was "the way to avoid bloodshed."118

Considerable thought went into the section on Northern Ireland that finally went into the government's White Paper of November 1975. In the first place the NIO insisted on Northern Ireland being covered by the document after a first draft omitted any mention of it. ${ }^{119}$ The NIO's motivation related to the need to stress the appropriateness of a different approach being taken in the Northern Ireland case from that of Scotland and Wales in view of the political capital the UUUC would be likely to make out of the proposals: "The Scottish model of devolution will inflame Unionists in Northern Ireland-particularly as it is possible that it may not be practicable to have any form of devolution in Northern Ireland at the present time." 120 The thinking in the NIO was that the proposals for Scotland would only serve to re-intensify the Unionist belief that power sharing rather than straightforward majority rule should not be imposed on Northern Ireland. Similarly, a proportional representation electoral system was not being proposed for Scotland but had been instituted in Northern Ireland.

The NIO saw it as their duty to point out some of the lessons of the Northern Ireland experience, and invariably this amounted to the advocacy of great caution regarding devolution for other parts of the United Kingdom and warnings about possible problems. The NIO senior official, Dennis Trevelyan, perhaps summed it all up best at this point when he wrote that there was a need "to make haste slowly" on devolution. ${ }^{121}$ Certainly much of the civil service advice reaching the government took the form of warnings about the possible clash of interests between the government's policies on Northern Ireland and on devolution in Britain. ${ }^{122}$ The influence brought to bear on the wider devolution question by Northern Ireland considerations was thus to take the form of slowing and watering down the process.

In the event, great efforts were made to ensure that the wording of the White Paper did not make it indefensible for government ministers to argue that Northern Ireland and Scotland required separate treatment. The section on Northern Ireland

\footnotetext{
116 "Call on the PM," 30 October 1975, TNA: PRO, CJ 4/784.

${ }^{117}$ Enoch Powell, speech, dated 11 September 1975, TNA: PRO, CJ 4/784.

118 "Call on the PM," 30 October 1975, TNA: PRO, CJ 4/784.

${ }^{119}$ Burns to Trevelyan, 22 September 1975, TNA: PRO, CJ 4/981.

${ }^{120}$ Ibid.

${ }^{121}$ Trevelyan memo, 7 October 1975, TNA: PRO, CJ 4/981. See also Davenport memo, 25 September 1975; "Devolution to Scotland and Wales," 2 October 1975; and Pickering memo, 7 October 1975, TNA: PRO, CJ 4/981.

${ }^{122}$ See A. J. Purkis's paper, "Draft Devolution Paper: Statements Which Might Compromise Policy towards Northern Ireland," 3 October 1975; also Burns memo, 2 October 1975, TNA: PRO, CJ 4/
} 745 . 
duly averred that the Province came into "a different category." Yet the import of this was somewhat diluted by the subsequent acknowledgment that England, Scotland, and Wales also differed from each other, and the resort to the fallback position that the "unity" of the United Kingdom did not mean that each of its constituent parts had to be administered in the same way. ${ }^{123}$ However, the deliberations leading up to the publication of the White Paper had also shown that proposals for one part of the United Kingdom necessarily held implications for the other parts and that the Scottish and Northern Irish cases in particular could not always be kept in different compartments.

\section{THE CALLAGHAN YEARS, 1976-79}

Harold Wilson resigned as prime minister on 16 March 1976 and was succeeded by James Callaghan, who won a protracted Labour leadership contest. One of Callaghan's strongest supporters was Rees, and the latter's reward was a move in September to the Home Office. Roy Mason became secretary of state for Northern Ireland, while the corresponding Scottish office went to Bruce Millan, notably more in favor of devolution than his predecessor, Willie Ross. The advent of Mason to Stormont Castle signaled a change of approach: the search for a political breakthrough was in effect swapped for a policy based on boosting jobs and security and thus providing, it was reasoned, a more solid basis for progress. Certainly, it can be argued that Callaghan's premiership and Mason's secretaryship terminated the destabilizing speculation about British withdrawal that had accompanied the last Wilson administration.

The Callaghan years were in fact more notable, politically, for the government's difficulties over its devolution legislation for Scotland and Wales than for its handling of Northern Ireland. The Scotland and Wales Bill, introduced in December 1976, faced serious opposition in the House of Commons, and the government had to resort to a guillotine motion, which it duly lost in February 1977. Twentytwo Labour MPs, mostly from north of England constituencies, voted against, and twenty-three abstained. The minority Labour government then formed a parliamentary pact with the Liberals, part of the price of which was new devolution legislation, this time in the form of separate bills for Scotland and Wales. These bills passed safely through the House, albeit with crucial amendments such as the stipulation that the devolved assemblies proposed should be granted only if at least 40 percent of the Scottish and Welsh electorates voted in favor in a referendum. ${ }^{124}$

From the introduction of the original bill in 1976 the debate was well and truly joined in Scotland. Pressure groups on both sides of the argument sprang up, and certain political figures in the controversy, most notably Tam Dalyell, became household names. ${ }^{125}$ Dalyell highlighted the conundrum of the voting rights of Scottish MPs at Westminster in the event of an Edinburgh Assembly, which took on the name of his constituency, "The West Lothian Question." The question was

\footnotetext{
${ }^{123}$ Our Changing Democracy, 2, par. 7. See also Democracy and Devolution: Proposals for Scotland and Wales, Cmnd. 5732 (London, 1974), 1, par. 3. Also Rees, Northern Ireland, 323.

${ }^{124}$ For a clear account of these political developments, see Bogdanor, Devolution, chap. 6.

${ }^{125}$ See Graham Walker, "The 'Scotland Is British' Campaign," Scottish Affairs, no. 61 (Autumn 2007): 74-100.
} 
not new, having been raised in the debates over Irish Home Rule in the late nineteenth and early twentieth centuries; moreover, there had been in effect the "West Belfast Question" for the duration of Northern Ireland's devolution experience from 1921 until 1972, when the Province's MPs at Westminster could, and indeed did, vote on issues pertaining only to Scotland, England, and Wales. This matter was recalled by Labour opponents of devolution at this time, the argument being that what was thought of as "a tolerable oddity" in relation to a dozen Ulster Unionist MPs would become a constitutional crisis in the case of seventy-one Scottish MPs. ${ }^{126}$

For Dalyell, the whole debate in Scotland was "haunted by the spectre of Ireland." ${ }^{27}$ Certainly, Irish questions and parallels claimed the attention of both sides in the Scottish debate, and both were to use Northern Ireland to support their respective cases. For the most part, however, politicians employed an Irish dimension in these arguments to instill fear and anxiety and to discourage voters either from supporting devolution or from supporting the constitutional status quo. The prodevolutionsts, for instance, were inclined to argue that the denial of self-government to the Scots would mean turning the country into another Ireland and possibly provoking political violence. Conversely, antidevolutionists contended that a devolved assembly would lead to friction between Edinburgh and London and embitter Anglo-Scottish relations along parallel lines to those of the Irish and the English earlier in the century. ${ }^{128}$ The antidevolutionists also exploited the Northern Ireland devolution history to make a point about the dangers of one issue dominating the country's politics: in Ulster it had been the question of loyalty to the state and the British connection; in Scotland it would be the question of whether devolution would prove to be a constitutional terminus or a stepping stone to independence. ${ }^{129}$ They pointed to the dangers of unbroken one-party rule, as had been the case in Northern Ireland between 1921 and 1972, and the possibility of a similar scenario in Scotland. ${ }^{130}$ Dalyell indeed implied that the kind of sectarian problems bedevilling Northern Ireland would be far likelier to develop in a "small, inward-looking" governmental set-up, as proposed for Scotland, than in the context of London rule. ${ }^{131}$ Both camps were certainly aware of the potential for sectarian trouble that still existed in Scotland, particularly in the west of the country, where there was much popular support for the respective Unionist and Nationalist causes in Northern Ireland and where, for example, the Orange Order retained a strong presence.

At Westminster, the UUP, led there by Molyneaux and Powell, wrung from the Callaghan government the increase in the number of Northern Ireland MPs suggested by the Kilbrandon Report, from twelve to seventeen. For as long as devolution was blocked from returning to Stormont-and in the deadlocked aftermath of the convention's failure this looked like being indefinite-the Unionists

\footnotetext{
${ }^{126}$ ABC of Devolution (n.d., probably 1978), pamphlet published by Labour "Vote No" Campaign.

${ }^{127}$ Tam Dalyell, The End of Britain? (London, 1977), 285.

${ }^{128}$ Walker, "Scotland Is British."

${ }^{129}$ Ibid.

${ }^{130}$ See Graham Walker, Intimate Strangers: Political and Cultural Interaction between Scotland and Ulster (Edinburgh, 1995), 150-55; James Kellas, The Scottish Political System (Cambridge, 1979), 140-41; Brian Lapping, The Labour Government, 1964-70 (Harmondsworth, 1970), 199.

${ }^{131}$ Dalyell, End of Britain? 293.
} 
could focus on addressing some of the democratic deficits inherent in the direct rule system. In this task Molyneaux and the UUP made liberal use of the Scottish model of administrative devolution in calling for reforms to the Northern Ireland arrangements. ${ }^{132}$ Yet Unionists in Northern Ireland seemed in general still convinced that only the return of their own parliament would secure their position, and the UUP leader Harry West epitomized the image of the dour "UlsterScot." ${ }^{133}$ In Scotland, the Orange Order's support for the return of a Unionistdominated Stormont extended to a prodevolution stance for its own country that complicated the picture among pro-Union Scots. ${ }^{134}$

Indeed, it is difficult to assess how much influence Irish issues might have exerted on the thoughts of voters when the devolution referendum was eventually held in March 1979. As well as the Orange Order's pro-Assembly position, it has been suggested that many Catholics in Scotland feared, or were encouraged to fear, a Scottish Assembly becoming another Stormont and an instrument of Protestant domination. ${ }^{135}$ On the other hand, recent research casts serious doubt on the significance of a Catholic "No" vote in 1979..$^{136}$

Ultimately, the Irish question appears to have had little direct influence, while hovering, rather menacingly, in the background. The indecisive result of the devolution referendum, the subsequent fall of the Callaghan government, and the election of the Conservatives under Margaret Thatcher were to alter the foundations for the next phase in the intertwined histories of UK constitutional reform, Scottish devolution, and the search for peace in Northern Ireland.

\section{CONCLUSION}

It has been a well-established line of criticism of the Labour government's constitutional reform program since it took power in 1997 that it has lacked coherence. The government's piecemeal approach has been defended with reference to the diverse nature of the United Kingdom and the lack of a written constitution, but there is little doubt that a tendency to focus too narrowly and to miss the implications and consequences for the "bigger picture" has been markedly in evidence. Yet this observation can also apply to earlier episodes around devolution and constitutional debate. This article has attempted to show, with particular reference to Scotland and Northern Ireland, that connections between different parts of the United Kingdom have often revealed weaknesses in central government's appreciation of the problems at hand and insufficiently developed structures and practices of intergovernmental relations and coordination.

Any account of the history of devolution as an idea, of its practical operation, or of its significance in the context of evolving political debate and the concerns of successive governments is incomplete without an Irish dimension. ${ }^{137}$ Northern

\footnotetext{
${ }^{132}$ Kaufmann, Orange Order, 108.

${ }^{133}$ Walker, Ulster Unionist Party, 225.

${ }^{134}$ Walker, Intimate Strangers, 155-60.

${ }^{135}$ Tom Gallagher, Glasgow: The Uneasy Peace (Manchester, 1987), 327.

${ }^{136}$ Michael Rosie, The Sectarian Myth in Scotland (Basingstoke, 2004), 58-60.

${ }^{137}$ Jackson, Home Rule, is authoritative on the Irish dimension but rarely relates it to the wider UK devolution debate.
} 
Ireland's distinction of being the United Kingdom's first experiment in legislative devolution has been of great political significance, as evidenced above, whether in the context of the Home Rule ferment surrounding Scotland in the late 1940s or that of the broader UK debate of the 1970s. In addition, the need to find a political solution to the troubles of the Province in the 1970s had the effect of complicating the issue of devolution for other parts of the United Kingdom. It is also intriguing to wonder if the Northern Ireland troubles could have been prevented by the "all round" devolutionary or "federal" restructuring of the United Kingdom that emerged in the thinking of a few far-sighted political figures, such as Richard Crossman and John P. Mackintosh, in the 1960s. ${ }^{138}$ Finally, what has been presented here might also be regarded as a contribution to a more searching appreciation of the relationship between Scotland and Northern Ireland over a period of thirty or so years and an aid to understanding the often ambiguous political effects and expressions of a relationship that was so intimate on a social and cultural level.

${ }^{138}$ See the discussion in Steven Fielding, Labour and Cultural Change (Manchester, 2003), chap. 